\title{
Pediocin SA-1: A selective bacteriocin for controlling Listeria monocytogenes in maize silages
}

\author{
Isabel R. Amado, ${ }^{* 1}$ Clara Fuciños, ${ }^{* \dagger}$ Paula Fajardo, $\ddagger$ and Lorenzo Pastrana§ \\ *Departamento de Química Analítica y Alimentaria, Facultad de Ciencias de Ourense, Universidad de Vigo, As Lagoas s/n 32004, Spain \\ †Centre of Biological Engineering, University of Minho, 4710-057 Braga, Portugal \\ †ANFACO-CECOPESCA, Colegio Universitario 16, 36310 Vigo, Pontevedra, Spain \\ §International Iberian Nanotechnology Laboratory, Avda. Mestre José Veiga s/n, 4715 Braga, Portugal
}

\begin{abstract}
In this study, we assessed the potential as silage additive of a bacteriocin produced by Pediococcus acidilactici Northern Regional Research Laboratory (NRRL) B-5627 (pediocin SA-1). Maize was inoculated either with a bacterial starter alone (I) or in combination with the bacteriocin (IP), and untreated silage served as control. We monitored the products of fermentation (ethanol, and lactic and acetic acids), the microbial population, and the presence of the indicator strain Listeria monocytogenes Colección Española de Cultivos Tipo (CECT) $4032\left(1 \times 10^{5} \mathrm{cfu} / \mathrm{g}\right)$ after $1,2,5,8,16$, and $30 \mathrm{~d}$ of ensiling. Our results indicated antilisterial activity of the bacteriocin, anticipating the disappearance of $L$. monocytogenes in IP compared with I and control silages. The PCR-denaturing gradient gel electrophoresis analysis revealed the addition of the bacteriocin did not affect the bacterial communities of the spontaneous fermentation, and the inoculant-containing bacteria (Lactobacillus plantarum, Lactobacillus buchneri, and Enterococcus faecium) were found in addition to the bacterial communities of untreated maize silages in I and IP silages. Both treatments increased the concentration of antimicrobial compounds (acetic acid, ethanol, and 1,2-propanodiol) and led to lower residual sugar contents compared with the control, which would provide enhanced aerobic stability. The fact that the identified species L. plantarum, L. buchneri, and $E$. faecium produce some of these inhibitory compounds, together with their persistence throughout the $30 \mathrm{~d}$ of fermentation, suggest these bacteria could actively participate in the ensiling process. According to these results, pediocin SA-1 could be used as an additive to control the presence of $L$. monocytogenes in maize silages selectively, while improving their fermentative quality and eventually their aerobic stability.
\end{abstract}

Received March 2, 2016.

Accepted July 5, 2016.

${ }^{1}$ Corresponding author: sabelara@uvigo.es
Key words: silage, lactic acid bacteria, antimicrobial, pathogenic bacteria

\section{INTRODUCTION}

Listeria monocytogenes is recognized worldwide as an important foodborne pathogen causing listeriosis. This bacterium, ubiquitous in the environment, has been isolated from different farm-produced foods such as vegetables, meat, and dairy products. Listeria monocytogenes is an important microbiological risk at the beginning of the food chain, and concern is increasing about this bacterial pathogen in foods. Moreover, considering L. monocytogenes can grow in unfavorable environments (anaerobiosis, pH shifts, high osmolarity, low temperature) and colonize environmental niches such as the gastrointestinal tract, soil, silages, and sludge (Lungu et al., 2009). This contamination has often been related to poorly fermented silage, which is considered one of the main factors leading to cattle infection (Borucki et al., 2005).

Ensilage consists of the fermentation of free sugars to lactic acid irrespective of forage by epiphytic microorganisms, mainly lactic acid bacteria (LAB), varying in number and composition during fermentation (Klocke et al., 2006). Silages are a traditional way to preserve cattle feed for extended periods of time when fresh forage is limited or unavailable. Lactic acid bacteria are traditionally used to improve the nutritional properties of silages and to prevent the growth of undesirable microorganisms (Holzer et al., 2003). In recent years, the use of LAB producing antimicrobial peptides able to inhibit spoilage microorganisms of the silages has been increasingly studied. Gollop et al. (2005) reported the antimicrobial activity of silages treated with different LAB-based inoculants, and Marciňáková et al. (2008) observed positive effects of a bacteriocinogenic strain of Enterococcus faecium on the microbiological quality of grass silage. Amado et al. (2012) found the bacteriocinogenic LAB Lactococcus lactis Colección Española de Cultivos Tipo (CECT) 539 and Pediococcus acidilac- 
tici Northern Regional Research Laboratory (NRRL) B-5627, together with the ensiling strain Lactobacillus plantarum CECT 220, were able to control the occurrence of $L$. monocytogenes in grass and maize silages. More recently, Silva et al. (2016) reported the inoculation of alfalfa with a potential bacteriocinogenic Pediococcus pentosaceus strain improved the fermentation profile in tropical conditions, although no antimicrobial effect was observed.

The production of pediocin by $P$. acidilactici NRRL B-5627 has long been studied in our group (Guerra and Pastrana, 2002, 2003; Guerra et al., 2005a,b). This bacteriocin (pediocin SA-1) has been isolated and characterized (Anastasiadou et al., 2008), exhibiting a broad spectrum of activity against several foodborne pathogens, including L. monocytogenes (Guerra and Pastrana, 2002) and Listeria spp. (Anastasiadou et al., 2008). Pediocin SA-1 has high heat stability at acidic pH (3.7; Guerra and Pastrana, 2002) and low temperature $\left(30^{\circ} \mathrm{C}\right)$ within a wide range of $\mathrm{pH}(3.0-12.0$; Anastasiadou et al., 2008). Besides, the strain P. acidilactici NRRL B-5627 has shown to have a probiotic effect when tested as a feed additive for weaned piglets and has proven to be resistant to acid and bile salts in vitro (Guerra et al., 2007). For these reasons, this bacteriocin has a high potential value for ensiling purposes and as an additive for the animal feed industry.

The aim of this work was to study the use of pediocin from P. acidilactici NRRL B-5627 as an additive for maize ensiling. We evaluated the potential of pediocin SA-1 to remove L. monocytogenes from maize silages, as well as its effect on the products of fermentation and the naturally occurring microbiota.

\section{MATERIALS AND METHODS}

\section{Bacterial Strains and Inoculants}

Pediococcus acidilactici NRRL B-5627 and L. monocytogenes CECT 4032 were obtained from NRRL (Peoria, IL), and CECT (Valencia, Spain), respectively. The bacteria were maintained as frozen stocks at $-80^{\circ} \mathrm{C}$ in de Man, Rogosa, Sharpe (MRS) and brain heart infusion (BHI), respectively (Cultimed Panreac Química S.A., Barcelona, Spain), containing 30\% (vol/vol) glycerol and were propagated twice in appropriate medium before use. All cultures were grown in 250-mL Erlenmeyer flasks with $50 \mathrm{~mL}$ of medium, on a rotary shaker at $30^{\circ} \mathrm{C}$ (or $37^{\circ} \mathrm{C}$ in the case of $L$. monocytogenes) for $12 \mathrm{~h}$

We used a commercial inoculant specially formulated to enhance maize fermentation (11C33, Pioneer Hi-Bred International Inc., Johnston, IA), which consisted of a mixture of Lactobacillus buchneri ATCC PTA-2494, L. plantarum (ATCC 53187 and ATCC 55942), and E. faecium ATCC 55593.

\section{Pediocin Production}

Pediocin was produced in cultures of $P$. acidilactici NRRL B-5627 in MRS at $30^{\circ} \mathrm{C}$ in a laboratory fermentor, under $200 \mathrm{rpm}$ agitation conditions. We followed a fed-batch and re-alkalized cultivation mode that was reported to enhance significantly the synthesis of pediocin (Guerra et al., 2005b). When the growth and the capacity to recover the acidic $\mathrm{pH}$ of $P$. acidilactici stopped (92 $\mathrm{h}$ of culture), the $\mathrm{pH}$ of the medium was adjusted to 3.5 to promote the release of the bacteriocin from the cell surface. Then, the culture broth was heated for $3 \mathrm{~min}$ and centrifuged at 27,200 $\times g$ for 15 min at $4^{\circ} \mathrm{C}$ to remove the cells. Finally, the cell-free supernatant containing the total antibacterial activity was subjected to an ultrafiltration-diafiltration process to allow the concentration of the bacteriocinogenic activity while reducing the content of high molecular weight compounds of the culture broth. For this purpose, a Prep/Scale-TFF $6 \mathrm{ft}^{2}$ cartridge (Millipore Corporation, Billerica, MA), equipped with a polyethersulfone membrane of $10 \mathrm{kDa}$ was used, and the permeate containing the bacteriocin $(2,700 \mathrm{Da})$ was frozen at $-20^{\circ} \mathrm{C}$ until further use.

\section{Antibacterial Activity Assays}

The in vitro antibacterial activity of the pediocin extract was determined both against 12-h cultures of the commercial inoculant and against the strain L. monocytogenes CECT 4032. The quantitative antibacterial activity of the ultrafiltered cell-free supernatants was estimated by using a photometric bioassay (Cabo et al., 2001). Briefly, pediocin SA-1 was serially diluted in sterile distilled water, and 1-mL aliquots of the diluted samples were added in sterile culture tubes. Each tube was inoculated with $1 \mathrm{~mL}$ of either a culture of the commercial inoculant in MRS or L. monocytogenes in BHI, which was diluted to an initial absorbance of 0.2 with sterile buffered culture broth ( $\mathrm{pH}$ 6.8) just before use. Controls consisted of samples where the bacteriocin was replaced by sterile distilled water. Samples were then incubated at either $30^{\circ} \mathrm{C}$ (inoculant) or $37^{\circ} \mathrm{C}$ (L. monocytogenes) for $6 \mathrm{~h}$. Dose-response curves were obtained by plotting the absorbance at $700 \mathrm{~nm}$ against the inverse of the dilution of the antimicrobial compound. The antibacterial activity was expressed as bacteriocin activity units $(\mathbf{B U}) / \mathrm{mL}$, where $1 \mathrm{BU} /$ $\mathrm{mL}$ is the amount of antibacterial compound needed to 
obtain a $50 \%$ of growth inhibition compared the control (Guerra et al., 2005b).

\section{Silage Preparation}

Maize was harvested at the Centro de Investigaciones Agrarias de Mabegondo (La Coruña, Spain) and immediately chopped (10 $\mathrm{mm}$ length of cut) in the field using a conventional forage harvester. The chopped maize was transported under refrigeration (less than $2 \mathrm{~h}$ ) to the laboratory and wilted outdoors for approximately $3 \mathrm{~h}$ to a final DM content of $435 \mathrm{~g} / \mathrm{kg}$. We prepared portions (each treated individually) containing $1.5 \mathrm{~kg}$ of wilted maize for each treatment (for a total of 4.5 $\mathrm{kg}$ ). We sprayed each batch with $15 \mathrm{~mL}$ of either deionized water, control; LAB commercial inoculant (I), and LAB commercial inoculant + pediocin (IP), and thoroughly mixed. The inoculant supplied as a freezedried powder, containing a mixture of $L$. plantarum, $L$. buchneri, and E. faecium, was suspended in deionized water and applied at a rate of $1.1 \mathrm{mg} / \mathrm{kg}$ fresh forage according to the technical sheets, to provide $1 \times 10^{6}$ $\mathrm{cfu} / \mathrm{g}$.

One-hundred-gram samples of maize were packed in polyethylene bags designed for food use (dimensions 175 $\times 240 \mathrm{~mm}$ ), using a vacuum-packing machine (Elma, Udom SA, Álava, Spain). All bags were heat sealed, leaving a distance of $150 \mathrm{~mm}$ from the bottom and cutting the remaining plastic $5 \mathrm{~mm}$ above the sealing line. Before sealing, $1 \mathrm{~mL}$ of a L. monocytogenes CECT 4032 culture was added to the bags to obtain a concentration of approximately $1 \times 10^{5} \mathrm{cfu} / \mathrm{g}$ and mixed thoroughly.

Triplicate samples for each treatment and sampling time were incubated at $25^{\circ} \mathrm{C}$ for $30 \mathrm{~d}$. Two bags per treatment were opened at $1,2,5,8,15$, and $30 \mathrm{~d}$ after ensiling to perform chemical, microbiological, and PCR- denaturing gradient gel electrophoresis (DGGE) analyses.

\section{Chemical Analysis}

The DM content of maize and silages was determined by oven drying at $60^{\circ} \mathrm{C}$ until constant weight. For $\mathrm{pH}$ determination and chemical analysis, $20 \mathrm{~g}$ of silage sample was mixed with $180 \mathrm{~mL}$ of ultrapure water and twice homogenized in a Stomacher (model 400, Seward, London, UK). Aqueous extracts were filtered through Whatman paper grade 1 (11- $\mu \mathrm{m}$ pore size) to remove particulate matter, and centrifuged $(3,700 \times g$ for 10 min at $4^{\circ} \mathrm{C}$ ) for determining the water-soluble reducing sugars (Bernfeld, 1951). The concentration of organic acids (lactic, acetic, butyric, and propionic) and alcohols (ethanol, propane-1,2-diol, and butane-2,3-diol) was determined by HPLC analysis using an ION-300 Organic Acids column (length, $300 \mathrm{~mm}$; internal diameter, $7.8 \mathrm{~mm}$ ) with a precolumn Ionguard (Tecknokroma, Barcelona, Spain). The mobile phase was $3 \mathrm{mM}$ $\mathrm{H}_{2} \mathrm{SO}_{4}$ at a flow rate of $0.4 \mathrm{~mL} / \mathrm{min}$ at $65^{\circ} \mathrm{C}$, being the peaks detected with a refractive-index detector.

\section{Microbiological Analysis}

The LAB enumeration was determined in 20-g silage samples, mixed with $180 \mathrm{~mL}$ of sterile saline solution, and twice homogenized in a Stomacher (model 400, Seward, London, UK) for $1 \mathrm{~min}$. The number of LAB was obtained by pour plating serial 10-fold dilutions (in sterile saline solution) on MRS agar. The plates were overlaid with a thin layer of bacteriological agar (Cultimed Panreac Química S.A., Barcelona, Spain) and incubated at $30^{\circ} \mathrm{C}$ for 48 to $72 \mathrm{~h}$, before colony count. Only results between 30 and 300 colonies were considered and expressed as log colony-forming units per gram.

\section{DNA Extraction and PCR Amplification}

The DNA was extracted from 10-mL aliquots of the homogenates used for microbiological analysis, centrifuged at $13,000 \times \mathrm{g}$ for $5 \mathrm{~min}$ at $4^{\circ} \mathrm{C}$, following the procedure described elsewhere (Amado et al., 2012). Primers $357 \mathrm{~F}$ and R518 were used to amplify the V2-V3 variable regions of the total bacterial $16 \mathrm{~S}$ rRNA gene, which corresponds to the positions 339 of 539 from Escherichia coli (Gafan and Spratt, 2005). A region of the iap gene of the genus Listeria was amplified using the primers List-univ.1 and List-univ.2 (Cocolin et al., 2002). The expected size of amplified fragments, 170 bp for total bacteria and $460 \mathrm{bp}$ for L. monocytogenes, was verified on a $2 \%(\mathrm{wt} / \mathrm{vol}$ ) agarose gel. A GC clamp was added to the forward primers $357 \mathrm{~F}$ and List-univ. 1 , to improve the sensitivity of the detection of DNA sequence differences by DGGE analysis (Sheffield et al., 1989). The sequences of both pairs of primers and the specific conditions of each PCR are detailed in Table 1. The PCR was performed in a final volume of 50 $\mu \mathrm{L}$ using chemicals and enzymes provided by Bioline (London, UK).

\section{Denaturing Gradient Gel Electrophoresis}

The DGGE was performed on a Dcode system (BioRad Laboratories, Hercules, CA). The DNA fragments were loaded onto a polyacrylamide gel $(7.8 \mathrm{~g} / \mathrm{L}$ of polyacrylamide and $0.2 \mathrm{~g} / \mathrm{L}$ of Bis-acrylamide). According to conditions previously optimized in our laboratory, 
different denaturing gradients were used for total bacteria (30\% to $60 \%)$ and L. monocytogenes analysis $(20 \%$ to $40 \%$ ). The $100 \%$ denaturing conditions are defined as $7 \mathrm{M}$ urea containing $40 \%$ formamide.

Electrophoresis was run in a $1 \times$ Tris-acetate-EDTA buffer at $60^{\circ} \mathrm{C}$, for $16 \mathrm{~h}$ at $75 \mathrm{~V}$. After electrophoresis, gels were silver stained according to the method of Sanguinetti et al. (1994), scanned, and analyzed using the software Bionumerics 5.1 (Applied Maths, St-MartensLatem, Belgium).

The amplified fragments of interest were excised from the gel, resuspended overnight in Tris-EDTA buffer and amplified using the primers F357 (without GC clamp) and R518. The PCR products were purified using the GenElute PCR Clean-Up Kit (Sigma-Aldrich, St. Louis, MO) and sequenced using an ABI Prism 3130 DNA sequencer (Applied Biosystems, Foster City, CA). The consensus sequences were obtained after alignment and assembly using the software Geneious v3.6.1 (Drummond et al., 2008), performing the similarity searches within the GenBank databases using the BLAST program (http://www.ncbi.nlm.nih.gov/BLAST/).

\section{Statistical Analysis}

The data of final $\mathrm{pH}, \mathrm{LAB}$ counts (as log cfu/g), and concentrations of lactic acid, acetic acid, and ethanol were statistically analyzed using a general linear model procedure of the software package SPSS 15.0 for Windows (Release 15.0.1, 2006, SPSS Inc., Chicago, IL). First, Levene's test was used to determine if the variances of each variable were equal. Normal distribution of data between treatments was previously verified (via histograms). Then, a one-way ANOVA with the Tukey (in the case of equal variances) or Games-Howell (for unequal variances) post hoc test $(P=0.05)$ was used to determine whether there were significant differences between the mean final values of the variables.

\section{RESULTS AND DISCUSSION}

\section{In Vitro Antimicrobial Activity of Pediocin SA-1}

The interest in using bacteriocinogenic strains as inoculants for ensilage purposes focuses on their ability to inhibit the growth of undesirable microorganisms owing to the production of antimicrobial substances. However, one limitation to the application of bacteriocin-producing LAB in this field would be the ability of some of these bacterial strains to synthesize antimicrobial substances active against other LAB (Franz et al., 1996). For this reason, we initially tested the compatibility of pediocin SA-1 and the silage inoculant by performing an in vitro analysis of activity against 
a culture of the commercial inoculant (L. plantarum, E. faecium, and L. buchneri) in MRS. The results of the bioassay showed no inhibition of microbial growth at any of the concentrations tested (data not shown), indicating they could be successfully added together as silage inoculants.

Following analysis of dose-response data of the antimicrobial activity of pediocin SA-1 against a culture of L. monocytogenes CECT 4032, we found an inhibitory activity of $6,320 \mathrm{BU} / \mathrm{mL}$. This activity is 2 -fold higher than that reported against Carnobacterium piscicola, the usual indicator microorganism used to test the inhibition of $P$. acidilactici cell-free extracts (Guerra et al., 2005b). This result supports previously published qualitative results of antilisterial activity of pediocin SA-1 using the agar-diffusion method (Guerra and Pastrana, 2002).

\section{Monitoring L. monocytogenes in Maize Silages}

The genes of peptides with bacteriocin-like activity are found in a high proportion in Enterococci isolated from silage (Marciňáková et al., 2005; Strompfová et al., 2008). Indeed, several bacteriocins have been purified from different types of silage (Ohmomo et al., 2000; Eguchi et al., 2001; Sparo et al., 2006; Marciňáková et al., 2008; Bal et al., 2012). Some of these bacteriocins belonging to the pediocin-like family (Aymerich et al., 1996), and a bacteriocin isolated from Streptococcus bovis HC5 (Mantovani and Russell, 2003) have shown high antilisterial activity in vitro and bear a great potential as silage additives. However, to the best of our knowledge, this is the first report on the use of pediocin as an additive for controlling L. monocytogenes during the ensiling process.

Listeria monocytogenes is an important foodborne pathogen particularly in acidic foods such as silages (Caro et al., 1990) because of its high resistance to acidic pH (Barker and Park, 2001). Traditional detection methods of $L$. monocytogenes are based on enrichment techniques that might outnumber the nonpathogenic Listeria species when $L$. monocytogenes is present together with other Listeria sp., and might lead to false-negative results (Zittermann et al., 2016). Given the pathogenic potential of $L$. monocytogenes, PCR-based methods provide a more reliable detection of L. monocytogenes due to their high sensitivity (Zittermann et al., 2016). Indeed, previous reports have used DNA-based methods to identify L. monocytogenes in silages (Torriani and Pallotta, 1994; Amado et al., 2012; Sharifzadeh et al., 2015).

To evaluate the potential of pediocin SA-1 to remove L. monocytogenes from the silages, we used the strain L. monocytogenes CECT 4032 as an indicator of this

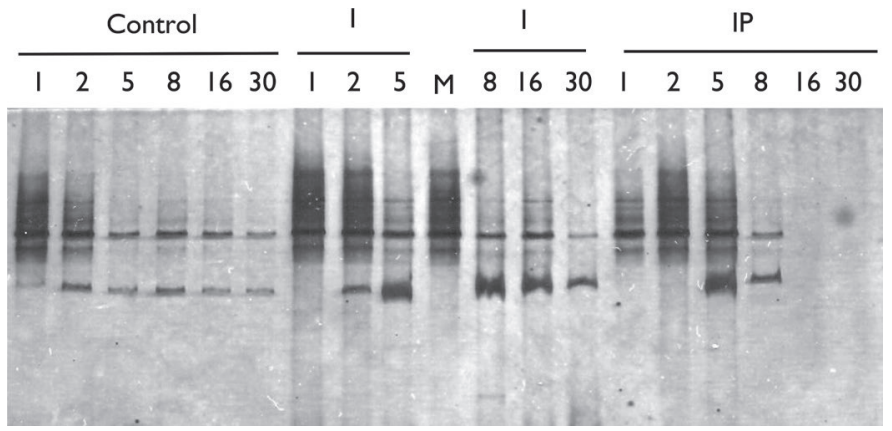

Figure 1. Denaturing gradient gel electrophoresis profiles of the PCR products from DNA extracted from maize silage under different treatments and times of fermentation: $1,2,5,8,16$, and $30 \mathrm{~d}$. I $=$ silages treated with Pioneer 11C33 inoculant; IP = silages treated with Pioneer 11C33 inoculant and pediocin SA-1. Amplification was performed using Listeria monocytogenes specific primers, List-univ.1 and List-univ.2. M corresponds to a marker from a pure culture of the L. monocytogenes Colección Española de Cultivos Tipo (CECT) 4032 added to the experimental silages.

pathogen. For this purpose, the bacterium was monitored in treated silages (I and IP) and untreated silages (control) during the $30 \mathrm{~d}$ of ensiling by comparing the DGGE profiles of the PCR products targeting the iap gene encoding a protein related to the virulence of $L$. monocytogenes (Figure 1). This methodology was first reported as a fast screening test to investigate the presence of Listeria spp. and L. monocytogenes in foods (Cocolin et al., 2002) and successfully applied to monitor the pathogen in ryegrass and maize silages (Amado et al., 2012).

The DGGE profiles showed a single band comigrating at the same distance of the L. monocytogenes marker strain, although a secondary band of unknown nature appeared whose pattern was not related to the treatment or the time of ensiling. The results of DNA analysis also revealed L. monocytogenes CECT 4032 disappeared after $8 \mathrm{~d}$ of ensiling in pediocin-treated silages, whereas it was still present after $30 \mathrm{~d}$ in the control and in I silages (Figure 1). The $\mathrm{pH}$ of silages after $5 \mathrm{~d}$ of ensiling (3.7; Figure 2) was reported to maximize the antibacterial activity of pediocin from P. acidilactici NRRL B-5627 (Guerra and Pastrana, 2002; Amado et al., 2012), accounting for the observed removal of L. monocytogenes after this time of ensiling. Besides, the stability of the bacteriocin at low $\mathrm{pH}$ values (3.0) and low temperature $\left(30^{\circ} \mathrm{C}\right.$; Anastasiadou et al., 2008) enhances antibacterial activity as the $\mathrm{pH}$ of the silage decreases, with the antibacterial activity maximized below a threshold $\mathrm{pH}$ of 3.7. This would be an advantage toward the use of Pediocin SA-1 as silage additive because the bacteriocin will maintain its activity in spite of the low $\mathrm{pH}$ of the silages. 
Effect of Pediocin Addition on the Chemical Composition, LAB Counts, and Bacterial Population of Maize Silages

Genomic DNA from maize silage samples was used to study the effect of the different treatments (I and IP) on their microbial profile using PCR-DGGE. This technique was reported as a rapid and reproducible tool for the analysis of the bacterial diversity in silages (Wang et al., 2006; Parvin et al., 2010). In agreement with other reports ( $\mathrm{Li}$ and Nishino, 2011), we observed a significant reduction in biodiversity compared with the

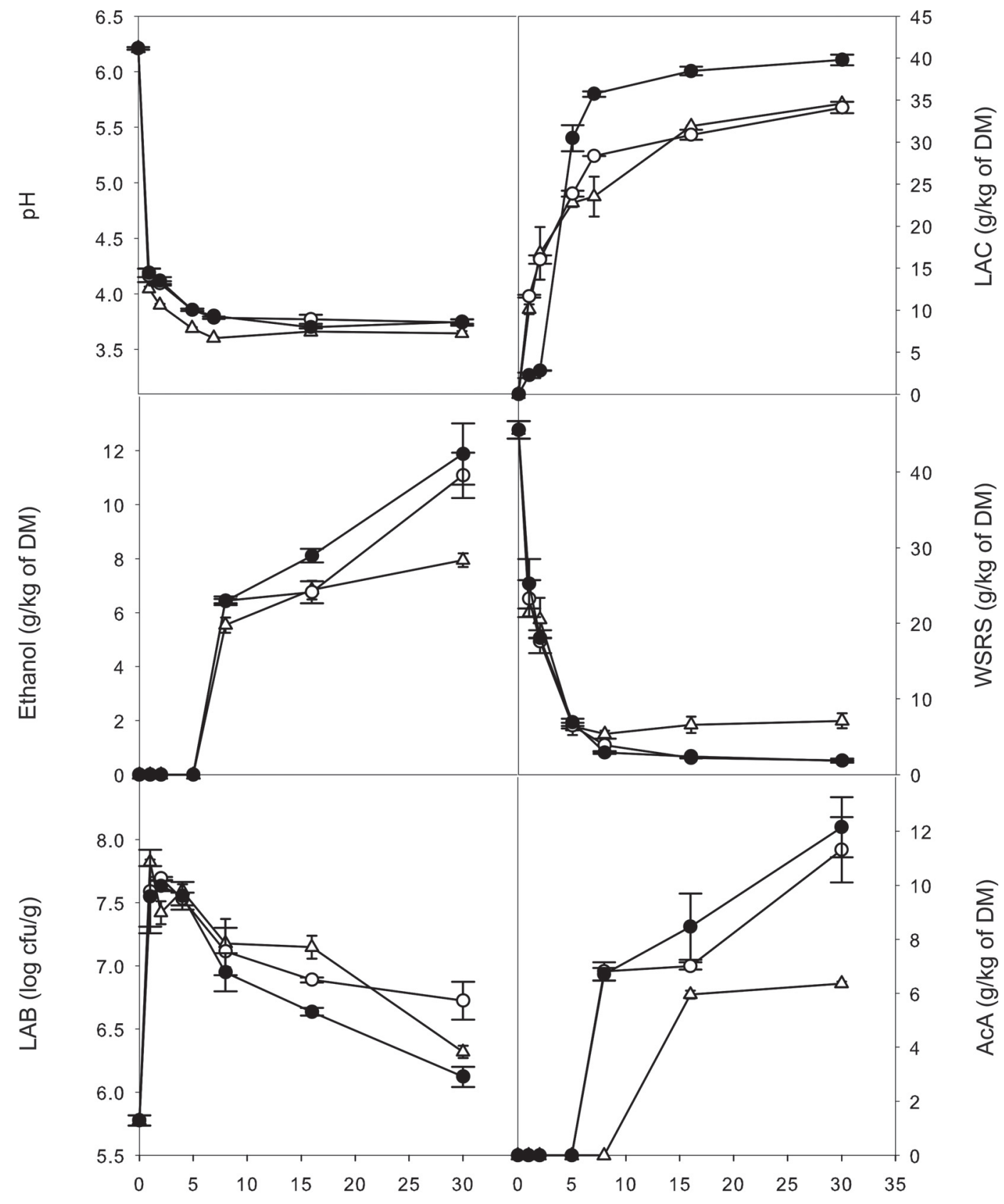

Time (d)

Time (d)

Figure 2. Changes in chemical composition and lactic acid bacteria (LAB) counts during maize fermentation. LAC, lactic acid; WSRS, water-soluble reducing sugars; AcA, acetic acid. Symbols: C, control silage $(\Delta)$; I, silages treated with Pioneer 11C33 inoculant $(O)$; IP, silages treated with Pioneer 11C33 inoculant and pediocin SA-1 $(\bullet)$. 
unfermented material (Figure 3). The onset of ensiling resulted in the disappearance of some indigenous bacteria (Figure 3), whereas other species such as P. pentosaceus, Pantoea agglomerans, and Klebsiella sp. (bands $10,12,13)$ disappeared in an early stage of fermentation (Table 2, Figure 3). By contrast, some species absent in the pre-ensiled crop appeared as the ensiling process begun and were identified as Lactobacillus brevis (band 1), Weissella cibaria (band 3), Weissella kimchii (band 4), a nonculturable Bacillus (band 5), and Weissella soli (band 7). At the same time, L. plantarum (band 6) and L. lactis (band 8) became more intense, remaining as the major species throughout ensiling, together with W. cibaria, W. kimchii, a nonculturable Bacillus, and

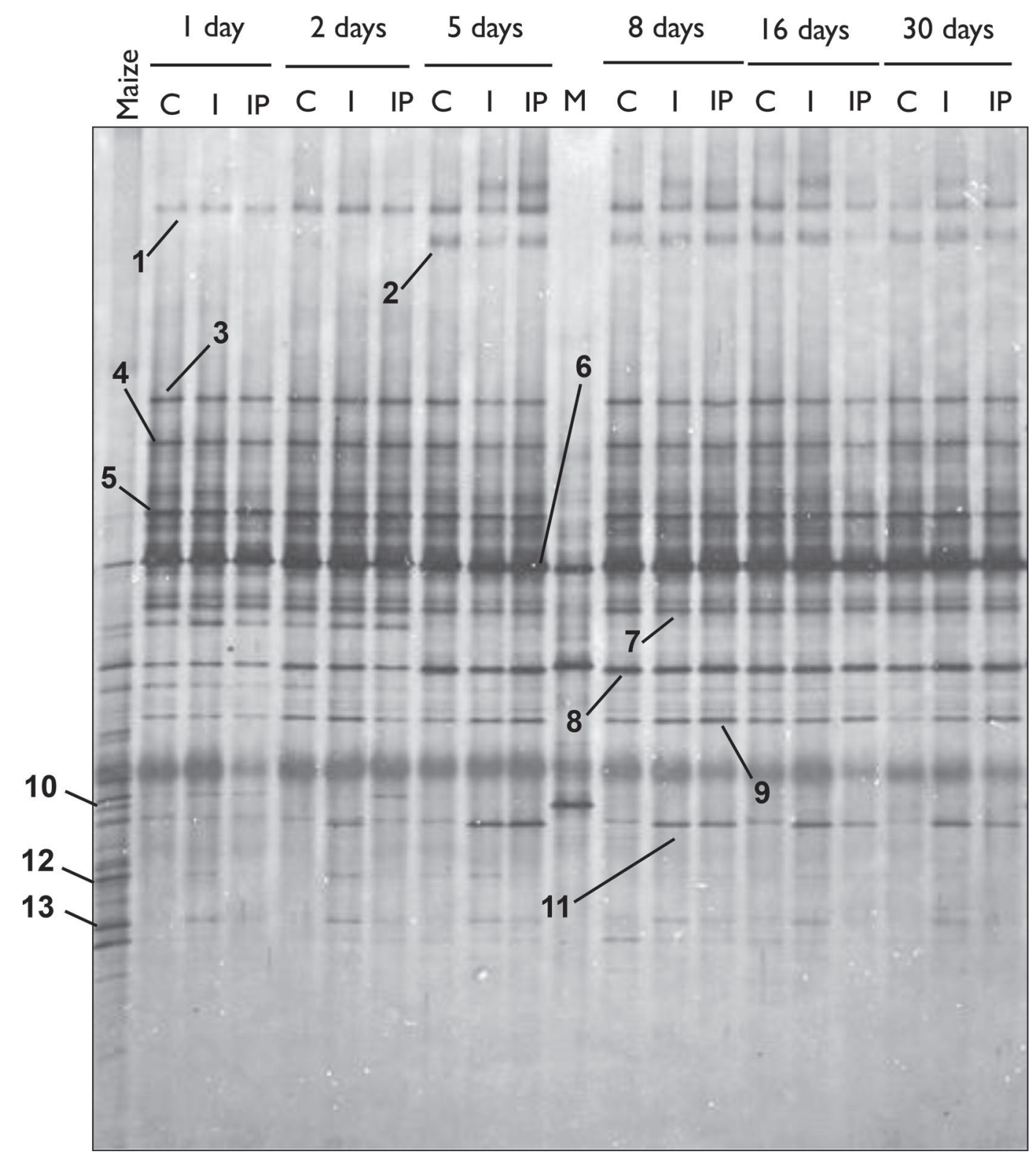

Figure 3. Denaturing gradient gel electrophoresis analysis of PCR-amplified $16 \mathrm{~S}$ ribosomal DNA fragments from maize silages at different times of ensiling: $1,2,5,8,16$, and $30 \mathrm{~d}$. C, control (untreated); I, silages treated with Pioneer 11C33 inoculant; IP, silages treated with Pioneer 11C33 inoculant and pediocin SA-1. M corresponds to a marker from pure cultures of L. plantarum, L. lactis, and P. acidilactici. The first lane on the left (Maize) corresponds to the untreated forage. The positions of bands discussed in the text are indicated by numbers that correspond to the following species of bacteria (Table 3): 1, Lactobacillus brevis; 2, Lactobacillus pentosus; 3, Weissella cibaria; 4, Weissella kimchii: 5 , uncultured Bacillus sp.; 6, Lactobacillus plantarum; 7, Weissella soli; 8, Lactococcus lactis; 9, Enterococcus faecium; 10, Pediococcus pentosaceus; 11, Lactobacillus buchneri; 12, Pantoea agglomerans; and 13, Klebsiella sp. 
W. soli both in treated and untreated silages (Figure 3 ). Less intense bands corresponding to $L$. pentosus (band 2) and L. brevis (band 1) appeared after the onset of fermentation. These changes in the bacterial population explain the observed increment in the LAB counts $(3 \log \mathrm{cfu} / \mathrm{g})$ within the early stage $(0-5 \mathrm{~d})$ of fermentation (Figure 2). The species L. plantarum and L. lactis (Parvin and Nishino, 2009; Parvin et al., 2010), L. brevis and L. pentosus (Wang et al., 2006; Parvin and Nishino, 2009), and various Weisella strains (Brusetti et al., 2006; Li and Nishino, 2013) have been identified in different silages.

Inoculation of maize either with or without pediocin did not substantially change the bacterial communities of the spontaneous fermentation. However, as expected, we observed an increase in the intensity of the bands corresponding to the inoculated species, E. faecium (band 9) and L. buchneri (band 11), which were also weak bands in untreated silages. These results are in agreement with previous findings showing inoculated LAB species (L. plantarum and L. brevis) detected in addition to bacterial communities in untreated maize silages (Parvin et al., 2010). The fact that inoculantcontaining bacteria (L. plantarum, L. buchneri, and E. faecium) were present throughout the $30 \mathrm{~d}$ of ensiling (Figure 3) suggest the bacterial inoculants could have an effect on silage quality, which might not occur if better adapted epiphytic microorganisms outcompete the inoculants and dominate the fermentation (Lin et al., 1992).

Within the initial stage of fermentation $(0-5 \mathrm{~d})$, our results revealed homolactic fermentation in both untreated and inoculated silages, characterized by lactic acid production and $\mathrm{pH}$ decrease (Figure 2). Heterofermentative bacteria are the predominant population in most untreated forages (Lindgren et al., 1983), so the high production of lactic acid must be due to the development of homofermentative L. plantarum and L. lactis observed during the initial stage of ensiling (Figure 3). Then, the growth of L. buchneri and, to a lesser extent of E. faecium, accounted for the higher production of acetic acid and propane-1,2-diol in treated silages than the control (Table 3). Listeria buchneri produces high levels of acetic acid in silage through converting lactic acid into acetic acid and propane-1,2-diol under anaerobic and acidic conditions (Oude Elferink et al., 2001). Acetic acid has antimicrobial activity against yeasts and molds (Tabacco et al., 2009) and has been shown to increase the aerobic stability of silages (Danner et al., 2003). Ethanol productions were similar throughout the time course of fermentation (Figure 2), although final compositions showed 38\% (I) and 49\% (IP) higher ethanol concentrations than untreated silage (Table 3). Hence, inoculation of maize either with or without pediocin increased the concentration of antimicrobial compounds compared with the spontaneous fermentation (Table 3), making them potentially less susceptible to yeast and mold growth as a consequence of aerobic exposure. However, further quantification of the inhibitory concentration of ethanol and propane-1,2-diol against spoilage microorganisms would be needed because the effective concentration of antimicrobial compounds in silages is usually quite high (Danner et al., 2003). The development of LAB observed during the initial phase of fermentation was responsible for the rapid sugar consumption (Figure 2 ), although final sugar concentrations were lower in inoculated series $(1.8 \mathrm{~g} / \mathrm{kg}$ of DM) compared with the control $(7.09 \mathrm{~g} / \mathrm{kg}$ of DM). The low sugar content also provides an advantage compared with the spontaneous fermentation because a high concentration of residual sugars could support yeast and mold growth (Filya et

Table 2. Identities of denaturing gradient gel electrophoresis bands isolated and purified from maize silages ${\text { (Figure } 3)^{1}}^{1}$

\begin{tabular}{lllc}
\hline Band & Closest species & Accession number & \% Similarity \\
\hline 1 & Lactobacillus brevis & GU295951 & 98.0 \\
2 & Lactobacillus pentosus & AB362751 & 99.0 \\
3 & Weissella cibaria & DQ294964 & 98.7 \\
4 & Weissella kimchii & AY190628 & 98.0 \\
5 & Uncultured Bacillus sp. & FJ95793 & 99.2 \\
6 & Lactobacillus plantarum & FJ867640 & 99.5 \\
7 & Weissella soli & AB485956 & 99.9 \\
8 & Lactococcus lactis & FJ915803 & 99.4 \\
9 & Enterococcus faecium & AF529204 & 99.8 \\
10 & Pediococcus pentosaceus & EU082182 & 98.7 \\
11 & Lactobacillus buchneri & FJ867641 & 98.5 \\
12 & Pantoea agglomerans & FJ756354 & 99.2 \\
13 & Klebsiella sp. & FJ912860 & 98.4 \\
\hline${ }^{1}$ The closest species name, accession number, and similarity percentage from performed Basic Local Alignment
\end{tabular}

Search Tool search are shown. 
Table 3. Composition of maize silages after $30 \mathrm{~d}$ of fermentation ${ }^{1}$

\begin{tabular}{|c|c|c|c|c|c|c|c|}
\hline Item & $\mathrm{pH}$ & $\begin{array}{c}\text { LAC } \\
(\mathrm{g} / \mathrm{kg} \text { of } \mathrm{DM})\end{array}$ & $\begin{array}{c}\mathrm{AcA} \\
(\mathrm{g} / \mathrm{kg} \text { of } \mathrm{DM})\end{array}$ & $\begin{array}{c}\text { Ethanol } \\
(\mathrm{g} / \mathrm{kg} \text { of } \mathrm{DM})\end{array}$ & $\begin{array}{c}\text { 1,2-Prop } \\
\text { (g/kg of DM) }\end{array}$ & $\begin{array}{c}\text { WSRS } \\
\text { (g/kg of DM) }\end{array}$ & $\begin{array}{c}\text { LAB } \\
(\log \mathrm{cfu} / \mathrm{g})\end{array}$ \\
\hline $\mathrm{C}$ & $3.64^{\mathrm{a}}$ & $34.6^{\mathrm{a}}$ & $6.36^{\mathrm{a}}$ & $7.94^{\mathrm{a}}$ & ND & $7.09^{\mathrm{a}}$ & $6.32^{\mathrm{a}}$ \\
\hline I & $3.74^{\mathrm{b}}$ & $34.1^{\mathrm{a}}$ & $11.3^{\mathrm{b}}$ & $11.1^{\mathrm{b}}$ & $18.3^{\mathrm{a}}$ & $1.82^{\mathrm{b}}$ & $6.72^{\mathrm{b}}$ \\
\hline SEM & 0.018 & 0.939 & 0.893 & 0.580 & & 0.889 & 0.088 \\
\hline$P$-value & 0.002 & $<0.001$ & $<0.001$ & $<0.001$ & & $<0.001$ & 0.002 \\
\hline
\end{tabular}

$\overline{\mathrm{a}, \mathrm{b}}$ Means from duplicate samples. Within columns, means followed by different letters are significantly different $(P<0.01)$.

${ }^{1}$ LAC, lactic acid; AcA, acetic acid; 1,2-Prop, 1,2-propanodiol; WSRS, water-soluble reducing sugars; LAB, lactic acid bacteria. ND, not detected (less than $0.2 \mathrm{~g} / \mathrm{kg}$ ).

al., 2000), which is an issue regarding aerobic stability (Pahlow et al., 2003). In agreement with these results, higher ethanol concentrations and sugar consumptions were found in alfalfa silages inoculated with $L$. buchneri, and with $L$. plantarum in combination with $E$. faecium (Filya et al., 2007), compared with other LAB inoculants and untreated silages. Lactic acid, acetic acid, and ethanol were the main fermentative products, along with propane-1,2-diol detected in treated silages after $30 \mathrm{~d}$ of ensiling (Table 3). However, we did not identify any production of propionic acid, butyric acid, and butane-2,3-diol (less than $0.2 \mathrm{~g} / \mathrm{kg}$ ) in any of the samples, which suggests a good fermentation quality.

The DGGE analysis of $16 \mathrm{~S}$ rRNA PCR products cannot detect active bacteria, but the fermentation products (acetic acid, propane-1,2-diol, and ethanol) coupled with the persistence of the inoculated species suggest these strains, actively participate in the ensiling process. The DGGE profiles also confirmed the results of the in vitro compatibility between the bacteriocin and the microorganisms contained in the commercial inoculant because no inhibition of $L$. plantarum, $E$. faecium, or L. buchneri was observed (Figure 3) in IP silages. Pediocin SA-1 did not affect the naturally occurring microbiota of the silages (Figure 3), whereas the removal of L. monocytogenes was observed after 8 $\mathrm{d}$ of ensiling (Figure 1). This result indicates a narrow spectrum of inhibitory activity that could be useful to control the spoilage microorganisms of silages selectively without affecting the harmless microbiota (Gálvez et al., 2007). This specificity would be an advantage compared with bacteriocins bearing a wider activity spectrum, such as enterocin ON-157 purified from an Enterococcus faecium strain isolated from a spoiled silage, and which was bactericidal against Listeria monocytogenes, but also enterococci and Lactobacillus sake (Ohmomo et al., 2000).

\section{CONCLUSIONS}

Pediocin SA-1 could be a potential silage additive that, together with a compatible bacterial inoculant $(L$. plantarum, L. buchneri, and E. faecium), selectively controls L. monocytogenes without affecting the beneficial microbiota of maize silages. In addition to not inhibiting the naturally occurring microbiota of the silages, higher concentrations of antimicrobial compounds were found in treated silages compared with the control, suggesting the inoculated species were involved in the ensiling process. The stability of pediocin SA-1 at low $\mathrm{pH}$ provides this bacteriocin a high potential toward its application as a food preservative and as an additive for the animal feed industry. However, further studies are needed to evaluate the real effects and the safety of this antimicrobial in field silage conditions.

\section{ACKNOWLEDGMENTS}

Isabel Rodríguez and Clara Fuciños were funded by a postdoctoral contract from the Xunta de Galicia, Spain (Plan I2C in 2012 and 2014, respectively). This research was financially supported by FP7 Project BiValBi (Biotechnologies to Valorise the regional food Biodiversity in Latin America; PIRSES-GA-2013-611493). We thank the Centro de Investigaciones Agrarias de Mabegondo for providing the maize used in this research. We also thank Pioneer Hi-Bred International Inc. for the inoculants and information supplied.

\section{REFERENCES}

Amado, I. R., C. Fuciños, P. Fajardo, N. P. Guerra, and L. Pastrana. 2012. Evaluation of two bacteriocin-producing probiotic lactic acid bacteria as inoculants for controlling Listeria monocytogenes in grass and maize silages. Anim. Feed Sci. Technol. 175:137-149.

Anastasiadou, S., M. Papagianni, G. Filiousis, I. Ambrosiadis, and P. Koidis. 2008. Pediocin SA-1, an antimicrobial peptide from Pediococcus acidilactici NRRL B5627: Production conditions, purification and characterization. Bioresour. Technol. 99:5384-5390.

Aymerich, T., H. Holo, L. S. Håvarstein, M. Hugas, M. Garriga, and I. F. Nes. 1996. Biochemical and genetic characterization of enterocin A from Enterococcus faecium, a new antilisterial bacteriocin in the pediocin family of bacteriocins. Appl. Environ. Microbiol. 62:1676-1682.

Bal, E. B. B., T. Isevi, and M. A. Bal. 2012. Characterization of an anti-listerial enterocin from wheat silage based Enterococcus faecium. J. Basic Microbiol. 52:496-503. 
Barker, C., and S. F. Park. 2001. Sensitization of Listeria monocytogenes to low $\mathrm{pH}$, organic acids, and osmotic stress by ethanol. Appl. Environ. Microbiol. 67:1594-1600.

Bernfeld, P. 1951. Enzymes of starch degradation and synthesis. Adv. Enzymol. 12:379-427.

Borucki, M. K., C. C. Gay, J. Reynolds, K. L. McElwain, S. H. Kim, D. R. Call, and D. P. Knowles. 2005. Genetic diversity of Listeria monocytogenes strains from a high-prevalence dairy farm. Appl. Environ. Microbiol. 71:5893-5899.

Brusetti, L., S. Borin, S. Mora, A. Rizzi, N. Raddadi, C. Sorlini, and D. Daffonchio. 2006. Usefulness of length heterogeneity-PCR for monitoring lactic acid bacteria succession during maize ensiling. FEMS Microbiol. Ecol. 56:154-164.

Cabo, M. L., M. A. Murado, M. P. González, J. A. Vázquez, and L. Pastoriza. 2001. An empirical model for describing the effects of nitrogen sources on nisin production. Lett. Appl. Microbiol. 33:425-429.

Caro, M. R., E. Zamora, L. León, F. Cuello, J. Salinas, D. Megias, M. J. Cubero, and A. Contreras. 1990. Isolation and identification of Listeria monocytogenes in vegetable byproduct silages containing preservative additives and destined for animal feeding. Anim. Feed Sci. Technol. 31:285-291.

Cocolin, L., K. Rantsiou, L. Iacumin, C. Cantoni, and G. Comi. 2002. Direct identification in food samples of Listeria spp. and Listeria monocytogenes by molecular methods. Appl. Environ. Microbiol. 68:6273-6282.

Danner, H., M. Holzer, E. Mayrhuber, and R. Braun. 2003. Acetic acid increases stability of silage under aerobic conditions. Appl. Environ. Microbiol. 69:562-567.

Drummond, A. J., B. Ashton, M. Cheung, J. Heled, M. Kearse, R. Moir, S. Stones-Havas, T. Thierer, and A. Wilson. 2008. Geneious v3.6. Accessed Jun. 21, 2009. http://www.geneious.com.

Eguchi, T., K. Kaminaka, J. Shima, S. Kawamoto, K. Mori, S.-H. Choi, K. Doi, S. Ohmomo, and S. Ogata. 2001. Isolation and characterization of enterocin SE-K4 produced by thermophilic enterococci, Enterococcus faecalis K-4. Biosci. Biotechnol. Biochem. 65:247-253.

Filya, I., G. Ashbell, Y. Hen, and Z. G. Weinberg. 2000. The effect of bacterial inoculants on the fermentation and aerobic stability of whole crop wheat silage. Anim. Feed Sci. Technol. 88:39-46.

Filya, I., R. E. Muck, and F. E. Contreras-Govea. 2007. Inoculant effects on alfalfa silage: Fermentation products and nutritive value. J. Dairy Sci. 90:5108-5114.

Franz, C. M. A. P., U. Schillinger, and W. H. Holzapfel. 1996. Production and characterization of enterocin 900 , a bacteriocin produced by Enterococcus faecium BFE 900 from black olives. Int. J. Food Microbiol. 29:255-270.

Gafan, G. P., and D. A. Spratt. 2005. Denaturing gradient gel electrophoresis gel expansion (DGGEGE). An attempt to resolve the limitations of co-migration in the DGGE of complex polymicrobial communities. FEMS Microbiol. Lett. 253:303-307.

Gálvez, A., H. Abriouel, R. L. López, and N. B. Omar. 2007. Bacteriocin-based strategies for food biopreservation. Int. J. Food Microbiol. 120:51-70.

Gollop, N., V. Zakin, and Z. G. Weinberg. 2005. Antibacterial activity of lactic acid bacteria included in inoculants for silage and in silages treated with these inoculants. J. Appl. Microbiol. 98:662-666.

Guerra, N. P., A. T. Agrasar, C. L. Macías, and L. Pastrana. 2005a. Modelling the fed-batch production of pediocin using mussel processing wastes. Process Biochem. 40:1071-1083.

Guerra, N. P., P. Fajardo Bernárdez, A. Torrado Agrasar, C. López Macías, and L. Pastrana Castro. 2005b. Fed-batch pediocin production by Pediococcus acidilactici NRRL B-5627 on whey. Biotechnol. Appl. Biochem. 42:17-23.

Guerra, N. P., and L. Pastrana. 2002. Modelling the influence of $\mathrm{pH}$ on the kinetics of both nisin and pediocin production and characterization of their functional properties. Process Biochem. $37: 1005-1015$.

Guerra, N. P., and L. Pastrana. 2003. Influence of $\mathrm{pH}$ drop on both nisin and pediocin production by Lactococcus lactis and Pediococcus acidilactici. Lett. Appl. Microbiol. 37:51-55.
Guerra, N. P., A. Torrado Agrasar, C. López Macías, P. Fajardo Bernárdez, and L. Pastrana Castro. 2007. Dynamic mathematical models to describe the growth and nisin production by Lactococcus lactis ssp. lactis CECT 539 in both batch and re-alkalized fedbatch cultures. J. Food Eng. 82:103-113.

Holzer, M., E. Mayrhuber, H. Danner, and R. Braun. 2003. The role of Lactobacillus buchneri in forage preservation. Trends Biotechnol. 21:282-287.

Klocke, M., K. Mundt, C. Idler, J. McEniry, P. O'Kiely, and S. Barth. 2006. Monitoring Lactobacillus plantarum in grass silages with the aid of $16 \mathrm{~S}$ rDNA-based quantitative real-time PCR assays. Syst. Appl. Microbiol. 29:49-58.

Li, Y., and N. Nishino. 2011. Bacterial and fungal communities of wilted Italian ryegrass silage inoculated with and without Lactobacillus rhamnosus or Lactobacillus buchneri. Lett. Appl. Microbiol. $52: 314-321$.

Li, Y., and N. Nishino. 2013. Effects of ensiling fermentation and aerobic deterioration on the bacterial community in italian ryegrass, guinea grass, and whole-crop maize silages stored at high moisture content. Asian-australas. J. Anim. Sci. 26:1304-1312.

Lin, C., K. K. Bolsen, B. E. Brent, and D. Y. C. Fung. 1992. Epiphytic lactic acid bacteria succession during the pre-ensiling and ensiling periods of alfalfa and maize. J. Appl. Bacteriol. 73:375-387.

Lindgren, S., P. Lingvall, A. Kaspersson, A. De Kartzow, and E. Rydberg. 1983. Effect of inoculants, grains, formic acid on silage fermentation. Swed. J. Agric. Res. 13:91-100.

Lungu, B., S. C. Ricke, and M. G. Johnson. 2009. Foodborne and gastrointestinal pathogen ecology and control in the intestinal tract. Anaerobe 15:7-17.

Mantovani, H. C., and J. B. Russell. 2003. Inhibition of Listeria monocytogenes by bovicin HC5, a bacteriocin produced by Streptococcus bovis HC5. Int. J. Food Microbiol. 89:77-83.

Marciňáková, M., A. Lauková, M. Simonová, V. Strompfová, and B. Koréneková. 2005. Occurrence of structural enterocin genes among silage enterococci. Bull. Vet. Inst. Pulawy 49:387-391.

Marciňáková, M., A. Lauková, M. Simonová, V. Strompfová, B. Koréneková, and P. Nad'. 2008. A new probiotic and bacteriocinproducing strain of Enterococcus faecium EF9296 and its use in grass ensiling. Czech J. Anim. Sci. 53:336-345.

Ohmomo, S., S. Murata, N. Katayama, S. Nitisinprasart, M. Kobayashi, T. Nakajima, M. Yajima, and K. Nakanishi. 2000. Purification and some characteristics of enterocin ON-157, a bacteriocin produced by Enterococcus faecium NIAI 157. J. Appl. Microbiol. 88:81-89.

Oude Elferink, S. J., J. Krooneman, J. C. Gottschal, S. F. Spoelstra, F. Faber, and F. Driehuis. 2001. Anaerobic conversion of lactic acid to acetic acid and 1,2-propanediol by Lactobacillus buchneri. Appl. Environ. Microbiol. 67:125-132.

Pahlow, R., E. Muck, F. Driehuis, S. J. W. H. Oude Elferink, and S. F. Spoelstra. 2003. Microbiology of ensiling. Silage Science and Technology 42:31-93.

Parvin, S., and N. Nishino. 2009. Bacterial community associated with ensilage process of wilted guinea grass. J. Appl. Microbiol. 107:2029-2036.

Parvin, S., C. Wang, Y. Li, and N. Nishino. 2010. Effects of inoculation with lactic acid bacteria on the bacterial communities of Italian ryegrass, whole crop maize, guinea grass and rhodes grass silages. Anim. Feed Sci. Technol. 160:160-166.

Sanguinetti, C. J., E. Dias Neto, and A. J. Simpson. 1994. Rapid silver staining and recovery of PCR products separated on polyacrylamide gels. Biotechniques 17:914-921.

Sharifzadeh, A., H. Momeni, P. Ghasemi-Dehkordi, and A. Doosti. 2015. Presence of Listeria monocytogenes in silage products of Shahrekord city. Asian Pac. J. Trop. Dis. 5:S133-S136.

Sheffield, V. C., D. R. Cox, L. S. Lerman, and R. M. Myers. 1989. Attachment of a 40-base-pair G+C-rich sequence (GC-clamp) to genomic DNA fragments by the polymerase chain reaction results in improved detection of single-base changes. Proc. Natl. Acad. Sci. USA 86:232-236.

Silva, V. P., O. G. Pereira, E. S. Leandro, T. C. Da Silva, K. G. Ribeiro, H. C. Mantovani, and S. A. Santos. 2016. Effects of lactic 
acid bacteria with bacteriocinogenic potential on the fermentation profile and chemical composition of alfalfa silage in tropical conditions. J. Dairy Sci. 99:1895-1902.

Sparo, M. D., M. S. Castro, P. J. Andino, M. V. Lavigne, C. Ceriani, G. L. Gutiérrez, M. M. Fernández, M. C. De Marzi, E. L. Malchiodi, and M. A. Manghi. 2006. Partial characterization of enterocin MR99 from a corn silage isolate of Enterococcus faecalis. J. Appl. Microbiol. 100:123-134.

Strompfová, V., A. Lauková, M. Simonová, and M. Marciňáková. 2008. Occurrence of the structural enterocin A, P, B, L50B genes in enterococci of different origin. Vet. Microbiol. 132:293-301.

Tabacco, E., S. Piano, L. Cavallarin, T. F. Bernardes, and G. Borreani. 2009. Clostridia spore formation during aerobic deterioration of maize and sorghum silages as influenced by Lactobacillus buchneri and Lactobacillus plantarum inoculants. J. Appl. Microbiol. 107:1632-1641.

Torriani, S., and M. L. Pallotta. 1994. Use of polymerase chain reaction to detect Listeria monocytogenes in silages. Biotechnol. Tech. $8: 157-160$

Wang, X., S. Haruta, P. Wang, M. Ishii, Y. Igarashi, and Z. Cui. 2006. Diversity of a stable enrichment culture which is useful for silage inoculant and its succession in alfalfa silage. FEMS Microbiol. Ecol. 57:106-115.

Zittermann, S. I., B. Stanghini, R. S. See, R. G. Melano, P. Boleszczuk, A. Murphy, A. Maki, and G. V. Mallo. 2016. Assessment of Listeria sp. interference using a molecular assay to detect Listeria monocytogenes in food. J. Food Prot. 79:138-143. 